\title{
Ketepatan pemberian solidaritas covid-19 terhadap usia lanjut (lansia)
}

\author{
Hilda Carmitha Panjaitan*, Frisca J. Burdam, Maria F. Penina Nanlohy \\ Fakultas Kedokteran dan Ilmu Kesehatan, Universitas Kristen Satya Wacana Salatiga, Indonesia \\ 472016016@student.uksw.edu \\ *Correspondent Author
}

Article history

Received 17 September 2020

Revised 15 November 2020

Accepted 23 Februari 2021

Keywords

COVID-19

Elderly

Social solidarity

Social stigma
During the COVID-19 pandemic, there was an increase in solidarity in the community. However, COVID-19 solidarity, which is not only given to vulnerable groups, can cause only a few elderly to receive assistance. This study aimed to analyze the accuracy of the targeting of COVID-19 solidarity assistance aimed at the elderly as the most vulnerable group, concerning things that can be understood about the elderly in the midst of the COVID-19 pandemic. This research is a descriptive study with a semi-quantitative approach. This research was conducted by tracing and analyzing news about Covid-19 Solidarity, which was published in online media. The research period was started from March to June 2020. Data collection techniques were carried out through documentation, observation, and literature studies. The study found that out of 352 news, only 16 news contained the target to the elderly. So it can be concluded that during the COVID-19 pandemic, only a few elderly received assistance. This is due to the negative stigma regarding the elderly. Suggestions for future researchers, to be able to research by gathering news in a larger number to get wider news information from each region.

This is an open-access article under the CC-BY-SA license.

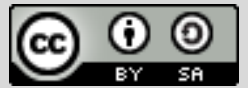

\section{Pendahuluan}

Pada Desember 2019, kasus COVID-19 pertama kali dilaporkan di Wuhan, Provinsi Hubei. Kasus ini kemudian meluas ke berbagai negara lain dalam durasi waktu tidak sampai satu bulan. Hingga saat ini, kondisi COVID-19 khususnya di Indonesia penambahan kasus terkonfirmasi masih terus meningkat hingga lebih dari 84.000 per Juli 2020, dengan penambahan kasus per hari mencapai lebih dari 1.000 kasus (1). Selama pandemi COVID-19, terjadi peningkatan solidaritas dan kepekaan social di masyarakat. Dalam hal ini, masyarakat mulai tergerak untuk melakukan berbagai aksi solidaritas social. Aksi solidaritas tersebut didasarkan oleh inisiatif kalangan masyarakat dengan tujuan untuk saling membantu dan meringankan beban sesama $(2,3)$. Sasaran pemberian solidaritas COVID-19 tersebut ditujukan kepada seluruh masyarakat yang turut terdampak secara ekonomi akibat adanya lonjakan pengangguran, kurangnya pendapatan serta adanya ketidakpastian pasar kerja sehingga berpotensi pada timbulnya masyarakat miskin baru $(4,5)$. Sayangnya, hal tersebut membuat pemberian solidaritas COVID-19 tidak dikhususkan bagi kelompok paling rentan yaitu kelompok lanjut usia atau lansia yang berusia di atas 60 tahun (6). 
Proses penuaan yang dialami oleh lansia menimbulkan kerentanan fisik dan kesehatan, yang membuat lansia rentan terhadap berbagai macam penyakit (7). Oleh karena itu, di tengah pandemi COVID-19, diharapkan lansia untuk tidak banyak menghabiskan waktu di luar rumah dan berada di tempat umum yang terdapat banyak kerumunan orang, agar lansia tidak menjadi korban penularan COVID-19. Namun, meskipun menjadi kelompok masyarakat paling rentan, dikarenakan kondisi fisik dan kesehatan yang menurun tersebut, nyatanya menurut Wahyu (2020) dalam masa pandemi COVID-19, masih banyak lansia yang melakukan aktivitas di luar rumah, seperti berbelanja kebutuhan sehari-hari, aktivitas perbankan secara manual maupun pekerjaan tertentu yang mengharuskan lansia untuk tetap bekerja di luar rumah(8), sehingga dalam menjalankan berbagai aktivitas tersebut, lansia perlu untuk menerapkan himbauan terkait protokol kesehatan agar dapat meminimalisir penularan COVID-19 selama beraktivitas. Sayangnya, himbauan tersebut hanya sedikit diterima oleh lansia, dikarenakan adanya perbedaan generasi yang membuat lansia sulit untuk mencerna atau memahami berbagai informasi, khususnya terkait COVID-19 (9).

Kondisi lansia yang tergolong rentan, seharusnya membuat masyarakat mengedepankan kelompok lansia sebagai sasaran dalam pemberian solidaritas COVID-19. Namun, pemberian solidaritas COVID-19 yang tidak hanya ditujukan bagi kelompok rentan, dapat menyebabkan sedikitnya lansia yang menerima bantuan selama masa pandemi COVID-19 hingga berisiko terabaikannya lansia selama masa COVID-19. Berdasarkan hal tersebut, maka tujuan dari penelitian ini adalah untuk menganalisa ketepatan sasaran pemberian bantuan solidaritas COVID19 yang ditujukan secara khusus kepada lansia sebagai kelompok paling rentan, berkaitan dengan hal-hal yang dapat dipahami mengenai lansia di tengah pandemi COVID-19.

\section{Metode}

Penelitian ini merupakan penelitian deskriptif dengan pendekatan semi-kuantitatif. Peneliti menggunakan analisis kualitatif untuk menjabarkan hasil analisis isi berita solidaritas COVID-19 bagi lansia, sedangkan analisis kuantitatif guna menghitung perbandingan jumlah berita solidaritas COVID-19 secara umum dengan yang ditujukan secara khusus bagi lansia. Penelitian ini dilakukan dengan menelusuri dan menganalisis berita terbaru setiap harinya, berkaitan dengan Solidaritas Covid-19 di seluruh Indonesia, baik dalam bentuk pemberian APD (Alat Pelindung Diri), sembako, dapur umum maupun terkait pembuatan lagu, yang termuat dalam media online dengan pencaharian melalui situs Google maupun media sosial, seperti Instagram. Waktu penelitian dimulai sejak proses penelusuran berita hingga analisis hasil pada bulan Maret 2020 hingga Juni 2020.

Teknik pengambilan sampel berita menggunakan teknik total sampling, dimana sampel yang diteliti berdasarkan dari jumlah keseluruhan populasi. Sehingga, objek penelitian analisis isi berita adalah keseluruhan berita terkait solidaritas COVID-19 yang diperoleh baik dari situs google maupun instagram pada rentang waktu Maret hingga Juni 2020, sedangkan untuk analisis isi, sampel data diperoleh dengan teknik purposive sampling, yaitu berita solidaritas COVID-19 yang memiliki sasaran pemberian kepada lansia. Teknik pengumpulan data yang dilakukan dalam penelitian ini adalah dokumentasi, observasi kumpulan berita dan studi pustaka. Kumpulan berita terkait solidaritas COVID-19 pada bulan Maret hingga Juni 2020 dipilih oleh peneliti dikarenakan pada waktu tersebut pemberitaan mengenai COVID-19 khususnya dalam pemberian solidaritas sangatlah banyak. Selanjutnya, dilakukan observasi terhadap seluruh kumpulan berita solidaritas COVID-19 yang telah terkumpul, secara khusus terkait kelengkapan berita melalui metode 5W + $1 \mathrm{H}$, lalu digunakan sebagai data primer. Sedangkan, data sekunder diperoleh melalui studi pustaka. Studi pustaka dilakukan dengan penelusuran literatur, jurnal dan beberapa buku untuk mendukung penelitian yang dilakukan, berhubungan dengan masalah pada penelitian.

Teknik analisis data dalam penelitian ini diolah dengan analisis deskriptif semi kuantitatif, dengan melakukan analisis isi berita melalui metode $5 \mathrm{~W}+1 \mathrm{H}$ secara khusus beritas solidaritas COVID-19 dengan sasaran lansia. Sedangkan analisis kuantitatif dilakukan dengan menghitung 
jumlah berita dengan sasaran lansia dari total keseluruhan berita solidaritas COVID-19. Keabsahan data diperoleh dengan menggunakan teknik pemeriksaan keabsahan oleh Lincoln dan Guba (1985), terdiri dari kredibilitas, transferabilitas, dependabilitas dan konfirmabilitas .

\section{Hasil dan Pembahasan}

Pandemi COVID-19 menyebabkan peningkatan solidaritas yang dilakukan oleh kelompok masyarakat dalam membantu sesama, khususnya masyarakat terdampak COVID-19. Penelitian ini berhasil menemukan 352 total berita yang berkaitan dengan pemberian solidaritas kepada masyarakat, dan sebanyak 16 berita diantaranya memuat lansia sebagai sasaran pemberian solidaritas COVID-19 (tabel 1). Berdasarkan hasil analisis dari total 352 berita, hanya 16 diantaranya yang memuat berita terkait pemberian solidaritas COVID-19 bagi lansia (Tabel 1).

Tabel 1. Daftar berita dari media online periode Maret hingga Juni 2020 terkait 16 berita dengan sasaran lansia dari total 352 berita solidaritas COVID-19.

\begin{tabular}{|c|c|c|c|c|c|}
\hline \multicolumn{2}{|c|}{ Tanggal } & Deskripsi Solidaritas & $\begin{array}{l}\text { Individu atau } \\
\text { Lembaga yang } \\
\text { Menginisiasi }\end{array}$ & \multicolumn{2}{|l|}{ Referensi } \\
\hline $\begin{array}{l}10 \\
2020\end{array}$ & April & $\begin{array}{l}\text { Presiden RI ke-6 Susilo Bambang } \\
\text { Yudhoyono atau SBY menciptakan } \\
\text { tembang seputar situasi wabah COVID- } \\
\text { 19, dengan judul 'Cahaya dalam } \\
\text { Kegelapan' yang secara khusus } \\
\text { ditujukan kepada kelompok lansia } \\
\text { agar tidak kehilangan harapan } \\
\text { ditengah badai COVID-19 }\end{array}$ & $\begin{array}{lr}\text { Presiden } & \text { RI } \quad \text { ke-6 } \\
\text { Susilo } & \text { Bambang } \\
\text { Yudhoyono } & \end{array}$ & Media online (10) & \\
\hline $\begin{array}{l}11 \\
2020\end{array}$ & April & $\begin{array}{l}\text { Pemuda dan mahasiswa di Liang, } \\
\text { Banggai Kepulauan, melakukan aksi } \\
\text { pembagian } 291 \text { masker gratis kepada } \\
\text { Warga yang kurang mampu dan lansia } \\
\text { di seluruh desa Liang dan sub desa Pal }\end{array}$ & $\begin{array}{l}\text { Pemuda dan } \\
\text { mahasiswa di Liang, } \\
\text { Banggai Kepulauan }\end{array}$ & Media online (11) & \\
\hline $\begin{array}{l}16 \\
2020\end{array}$ & April & $\begin{array}{l}\text { Gubernur Papua Barat melakukan } \\
\text { pembagian paket sembako kepada } \\
\text { masyarakat dan lansia }\end{array}$ & $\begin{array}{l}\text { Gubernur } \\
\text { Barat }\end{array}$ & $\begin{array}{l}\text { Media Sosial, } \\
\text { Instagram }\end{array}$ & yaitu \\
\hline $\begin{array}{l}17 \\
2020\end{array}$ & April & $\begin{array}{l}\text { PT Freeport Indonesia, melakukan aksi } \\
\text { sosial dengan membagikan sembako } \\
\text { kepada masyarakat Kabupaten Mimika } \\
\text { termasuk Lansia }\end{array}$ & $\begin{array}{l}\text { PT Freeport } \\
\text { Indonesia, Kabupaten } \\
\text { Mimika, Papua }\end{array}$ & $\begin{array}{l}\text { Media sosial, } \\
\text { Instagram }\end{array}$ & yaitu \\
\hline $\begin{array}{l}18 \\
2020\end{array}$ & April & $\begin{array}{l}\text { Anggota Fraksi Demokrat Desa } \\
\text { Tublopo melakukan aksi pembagian } \\
100 \text { masker kepada masyarakat, } \\
\text { terutama lansia, anak-anak dan remaja } \\
\text { serta penyemprotan cairan disinfektan } \\
\text { di rumah warga dan rumah ibadah } \\
\text { yang berada di Desa Mnelalete }\end{array}$ & $\begin{array}{lr}\text { Anggota } & \text { DPRD } \\
\text { Kabupaten } & \text { TTS } \\
\text { (Timor } & \text { Tengah } \\
\text { Selatan), Yudit Selan }\end{array}$ & Media online (12) & \\
\hline $\begin{array}{l}25 \\
2020\end{array}$ & April & $\begin{array}{l}\text { Kapolres Jayawijaya melakukan aksi } \\
\text { pembagian } 50 \text { paket sembako kepada } \\
\text { warakawuri pensiunan polri (lansia) }\end{array}$ & Kapolres Jayawijaya & Media online (13) & \\
\hline $\begin{array}{l}29 \\
2020\end{array}$ & April & $\begin{array}{l}\text { Denpom IV/5 Semarang melakukan } \\
\text { aksi pembagian sembako kepada } \\
\text { lansia serta masyarakat semarang } \\
\text { yang membutuhkan }\end{array}$ & $\begin{array}{lr}\text { Denpom } & \text { IV/5 } \\
\text { Semarang, } & \text { Jaw } \\
\text { Tengah } & \end{array}$ & $\begin{array}{l}\text { Media sosial, } \\
\text { Instagram }\end{array}$ & yaitu \\
\hline $\begin{array}{l}30 \\
2020\end{array}$ & April & $\begin{array}{l}\text { Polres Kabupaten Mimika membuka } \\
\text { dapur umum untuk membagikan } 1000\end{array}$ & $\begin{array}{l}\text { Polres } \\
\text { Mimika }\end{array}$ & Media online (14) & \\
\hline
\end{tabular}




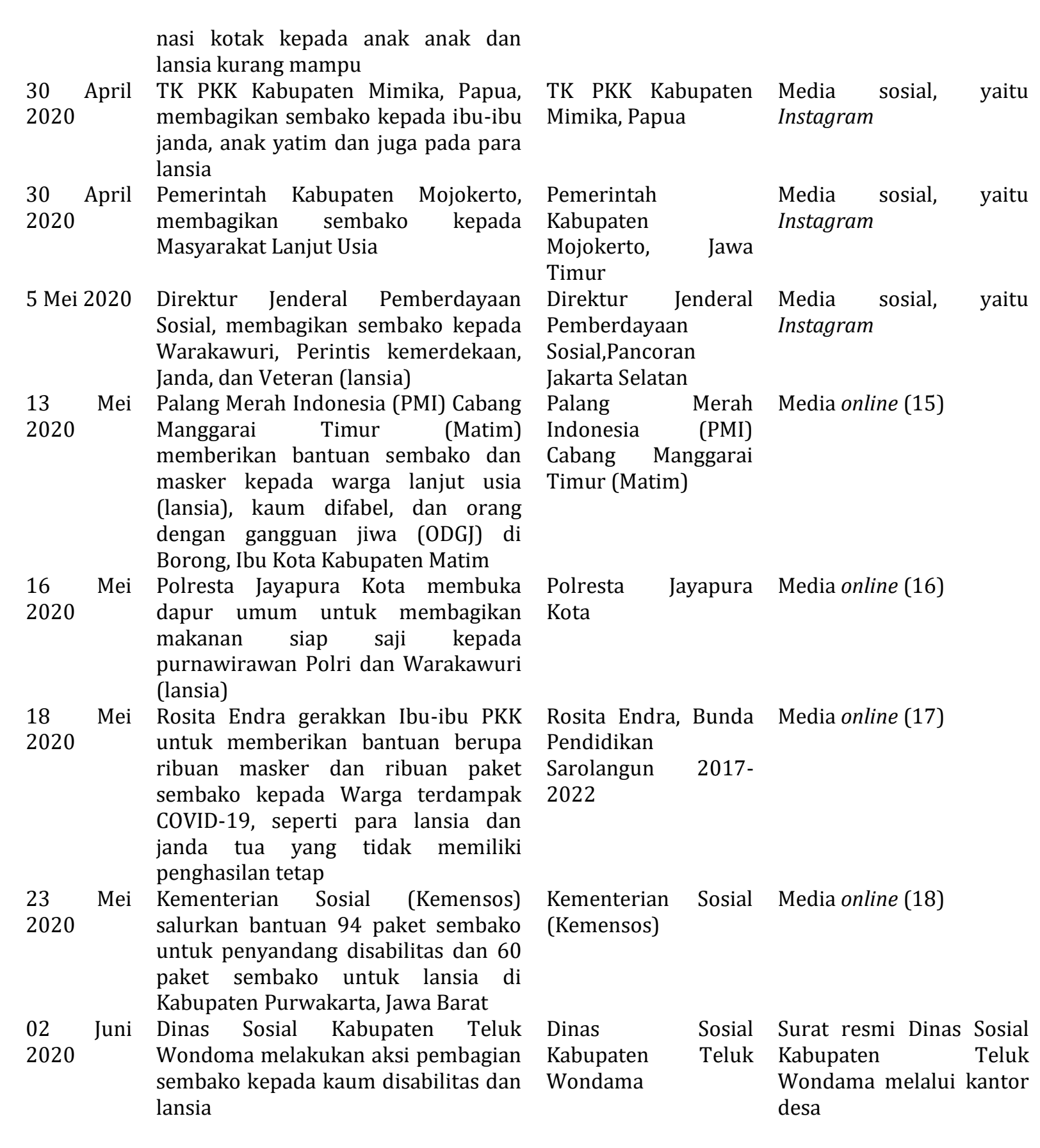

Dari table 1. dapat diidentifikasi bahwa hanya 4,54\% solidaritas ditujukan secara khusus kepada Lansia, sehingga hanya sebagian kecil lansia yang menerima solidaritas selama masa pandemi Covid-19. Dari sedikitnya 16 berita tersebut, dapat dilihat bahwa alasan mendasar dari 4,54\% masyarakat yang memberikan solidaritas COVID-19 bagi lansia ialah kesadaran akan rentannya kesehatan lansia dalam wabah COVID-19. Hal tersebut membuat beberapa masyarakat tergerak untuk memberikan bantuan APD (Alat Pelindung Diri) berupa masker, serta memberikan semangat melalui alunan lagu yang diciptakan secara khusus untuk menguatkan lansia dalam menghadapi pandemi COVID-19. Selain itu, alasan mendasar lainnya ialah banyaknya kelompok lansia yang terdampak secara ekonomi. Hal tersebut membuat beberapa masyarakat tergerak untuk memberikan bantuan melalui pembagian paket sembako serta pengadaan dapur umum yang menyediakan makanan siap saji bagi lansia . 
Jika dilihat dari berbagai alasan mendasar yang diungkapkan oleh sedikitnya 4,54\% masyarakat yang tergerak dalam memberikan solidaritas COVID-19 tersebut, terdapat dua hal yang dipahami oleh sedikitnya masyarakat terkait kerentanan lansia, yaitu dalam hal kesehatan serta perekonomian $(19,20)$. Sebagaimana menurut Adriani dan Wirjatmadi (2012), penuaan erat hubungannya dengan perubahan degeneratif yang akan menyebabkan lansia cenderung mengalami penyakit metabolik, yang bila tertular COVID-19 akan menimbulkan risiko lebih berat pada lansia dan gejala yang lebih parah dibandingkan dengan kelompok yang masih produktif (21). Hal ini dikarenakan sistem imun tubuh lansia yang lemah dan sifat virus yang akan menurunkan fungsi organ-organ tubuh lainnya sehingga dapat memperparah kondisi penderita.

Terkait dampak perekonomian yang dialami oleh lansia dalam masa pandemi COVID-19, sangat berhubungan dengan tingginya angka persentase lansia yang memenuhi kebutuhan finansial sendiri. Sebagaimana menurut Rossa (2020), sebanyak $47 \%$ lansia bekerja sendiri untuk kebutuhan dirinya, sedangkan 32\% lainnya menerima dari anak dan menantu (22). Dukungan finansial tersebut tentu belum dapat dikatakan cukup untuk memenuhi kehidupan sehari-hari, ditambah lagi situasi di tengah pandemi COVID-19 menyebabkan banyaknya pekerjaan yang harus dibatasi maupun diberhentikan. Hal tersebut semakin memperlemah perekonomian lansia.

Berbagai alasan mendasar tersebut, sudah cukup kuat untuk menjadikan lansia sebagai prioritas dalam pemberian solidaritas COVID-19, namun didapati fakta bahwa dari sekitar 352 berita terkait solidaritas COVID-19 yang dikumpulkan oleh peneliti, hanya 16 berita atau 4,54\% masyarakat yang tergerak dalam pemberian solidaritas COVID-19 yang ditujukan bagi lansia (tabel 1). Dari data tersebut dapat mengidentifikasi bahwa selama masa pandemi COVID-19, hanya sedikit lansia yang menerima bantuan, jika dibandingkan dengan total pemberian solidaritas COVID-19 kepada kelompok masyarakat lainnya. Sedikitnya masyarakat yang tergerak dalam pemberian solidaritas covid-19 bagi lansia dapat diidentifikasi oleh karena adanya stigma negatif mengenai lansia di tengah masyarakat. Menurut Sekretaris Komisi Daerah (Komda) Lansia DIY, Rustiyadi, kelompok lansia seringkali dianggap tidak produktif dan menjadi beban keluarga (23). Selain itu, masyarakat juga cenderung beranggapan bahwa lansia yang menderita suatu penyakit tergolong normal, dikarenakan hal tersebut merupakan akibat dari proses penuaan (24).

Konsekuensi dari kesenjangan yang dialami oleh kelompok lansia menjadi semakin besar di tengah pandemi COVID-19 (25), seperti yang terjadi di daerah Madrid, Spanyol, saat masa pandemi COVID-19, Departemen Kesehatan mengeluarkan protokol yang menyebutkan bahwa pasien lansia yang dirawat di panti jompo dan di rumah masing-masing serta tidak mandiri secara fisik dan memiliki disabilitas intelektual, tidak dapat dirawat di rumah sakit (26). Di Indonesia sendiri, kesenjangan dialami oleh lansia pada pelayanan kesehatan yang tergolong kurang, khususnya diberbagai daerah terpencil. Hal tersebut sesuai dengan hasil penelitian oleh Pramono dan Fanumbi (2012), yang menemukan bahwa seluruh lansia di semiurban tidak menerima pelayanan kesehatan khusus bagi lansia, dalam hal ini pelayanan kesehatan yang ada, tidak membedakan antara pasien lansia dan umum. Hal tersebut membuat lansia merasa tidak mendapatkan nasihat yang bermanfaat bagi kesehatan mereka (27). Dalam masa pandemi COVID19 pun, adanya program Jaringan Pengamanan Sosial (JPS) COVID-19 ditujukan bagi masyarakat, namun tidak terdapat program khusus bagi lansia di era COVID-19 (28). Kesenjangan yang dialami oleh lansia tersebut dapat diidentifikasi sebagai akibat dari berbagai stigma negatif yang membuat masyarakat berpendapat bahwa lansia tidak membutuhkan bantuan, sehingga memicu masyarakat kurang memprioritaskan lansia dalam pemberian solidaritas COVID-19 (29).

Padahal, jika dilihat kembali dari segi ekonomi, sebagian besar lansia aktif bekerja sendiri untuk memenuhi kebutuhan finansial (22). Bahkan menurut hasil penelitian Merodio dkk., (2020) terkait eksplorasi pengalaman lansia sebagai pasien COVID-19 di Madrid, Spanyol, menemukan bahwa pasien yang lebih tua (lansia) tetap turut peduli dan merawat pasien lainnya (19). Hal tersebut pun membuat pasien yang lebih muda tergerak untuk mengatur berbagai strategi dalam pemberian bentuk solidaritas. Hasil penelitian tersebut semakin memperkuat argumen bahwa sekalipun berada di masa sulit akibat COVID-19, lansia tetap turut aktif memberikan kontribusi berupa dukungan sosial bagi sesama. Fakta tersebut tentu membuktikan bahwa berbagai stigma 
negatif terkait ketidakproduktifan lansia dan pandangan lansia sebagai beban keluarga, merupakan stigma yang keliru. Hal tersebut sesuai dengan penelitian yang dilakukan oleh Ayu (2012), yang mengungkap bahwa lansia turut melakukan pekerjaan rumah tangga seorang diri dan tetap bekerja untuk anggota keluarga lainnya (30). Bahkan, Kelompok lansia yang tergolong aktif, maupun yang mengalami sakit atau disabilitas, memiliki potensi untuk tetap dapat aktif, produktif dan berkontribusi bagi masyarakat, dengan tujuan untuk meningkatkan kualitas hidup (25).

Sayangnya, akibat berbagai stigma negatif yang memicu diskriminasi, membuat keluarga terdekat hingga masyarakat kurang memperhatikan lansia sebagai kelompok paling rentan. Padahal, dalam keproduktifannya, lansia tetap membutuhkan kepedulian, terutama dari keluarga terdekat. Hal tersebut sesuai dengan penelitian Sarima, dkk (2017), yang menemukan bahwa terdapat hubungan yang signifikan dari dukungan sosial keluarga terhadap produktivitas lansia. Dukungan yang diberikan dapat berupa emosional, informatif, serta materi maupun nonmaterial (31).

Masalah lain yang membuat kerentanan lansia semakin tinggi ialah adanya keterbatasan lansia dalam mengakses informasi dan layanan kesehatan terkait COVID-19, sehingga membuat minimnya lansia yang menerapkan protokol kesehatan selama masa pandemi COVID-19. Hal tersebut sejalan dengan hasil penelitian yang dilakukan oleh Daoust (2020) di 27 negara, yang mengungkapkan bahwa kelompok lansia cenderung tidak melakukan isolasi mandiri dan mematuhi protokol kesehatan, seperti mencuci tangan serta menggunakan masker (20). Berkaitan dengan tingginya kerentanan lansia yang tidak menerapkan protokol kesehatan diakibatkan akses informasi yang kurang tersebut, sangat dibutuhkan dukungan dari masyarakat melalui solidaritas COVID-19, sebagai bentuk perhatian dan perlindungan terhadap lansia.

Solidaritas yang diberikanpun sangat perlu untuk tepat sasaran, khususnya menyeluruh bagi lansia sebagai kelompok rentan, sehingga tidak hanya sedikit lansia yang menerima bantuan sebagaimana dalam hasil penelitian ini yang menemukan bahwa hanya 4,54\% atau 16 solidaritas bagi lansia dari total 352 berita solidaritas bagi kelompok lainnya (32) . Bentuk solidaritas yang diberikan pun sudah tepat, namun perlu ditingkatkan dalam penyebaran pemberiannya bagi lansia, yaitu berupa edukasi serta APD (Alat Pelindung Diri) yang sangat dibutuhkan lansia di masa pandemi COVID-19 serta dukungan psikologi melalui alunan lagu yang sangat dibutuhkan sebagai bentuk dukungan dan penguatan bagi lansia. Solidaritas menyuluruh bagi lansia sebagai kelompok rentan pun sangat perlu untuk dilakukan, mengingat bahwa lansia baik yang memiliki keluarga maupun yang tidak lagi memiliki keluarga serta kerabat dekat, sangatlah bergantung terhadap dukungan sosial secara sukarela, hal tersebut pun guna menghindari rasa kesepian, terisolasi atau perasaan terpencil lansia selama masa pandemi COVID-19 $(9,19)$. Selain itu, adanya dukungan sosial dapat meningkatkan kualitas hidup serta membantu lansia dalam memenuhi kebutuhan hidup (33). Berbagai hal tersebut hanya dapat dilakukan jika masyarakat sadar akan kerentanan dan kebutuhan lansia tersebut, khususnya di masa pandemi COVID-19, dengan merubah stigma negatif mengenai lansia yang telah beredar di masyarakat.

\section{Kesimpulan}

Penelitian ini menemukan bahwa dari 352 berita terkait solidaritas COVID-19, hanya 16 berita yang memuat sasaran pemberian kepada lansia. Berdasarkan data tersebut, dapat diindetifikasi bahwa selama masa pandemi COVID-19, hanya sebagian kecil lansia yang menerima bantuan, jika dibandingkan dengan total pemberian solidaritas COVID-19 kepada kelompok masyarakat lainnya. Hal tersebut dikarenakan adanya stigma negatif mengenai lansia yang seringkali dianggap tidak produktif dan menjadi beban keluarga. Saran untuk peneliti selanjutnya yang ingin melakukan penelitian terkait analisa ketepatan sasaran pemberian bantuan solidaritas COVID-19 kepada lansia, untuk dapat melakukan penelitian dengan mengumpulkan berita dalam jumlah lebih banyak dan mencakup seluruh daerah di Indonesia, sehingga dapat memperoleh informasi berita yang lebih luas dari tiap daerah. 


\section{Ucapan Terimakasih}

Penulis mengucapkan terima kasih kepada Theresia Pratiwi Elingsetyo Sanubari, S.Si., M.Kes selaku Dosen pembimbing yang telah membantu dengan memberikan masukan bagi penulis selama menyelesaikan penelitian.

\section{Konflik Kepentingan}

Penulis menyatakan jika artikel ini tidak ada konflik kepentingan.

\section{Referensi}

1. Satgas Covid19. Peta Sebaran | Gugus Tugas Percepatan Penanganan COVID-19. Covid19.Go.Id. 2020.

2. Arora G, Kroumpouzos G, Kassir M, Jafferany M, Lotti T, Sadoughifar R, et al. Solidarity and transparency against the COVID-19 pandemic. Dermatol Ther. 2020;33(4):19-20.

3. Taylor AL, Habibi R, Burci GL, Dagron S, Eccleston-Turner M, Gostin LO, et al. Solidarity in the wake of COVID-19: reimagining the International Health Regulations. Lancet. 2020;396(10244):82-3.

4. Burhanuddin CI, Abdi MN. Ancaman Krisis Ekonomi Global dari Dampak Penyebaran Virus Corona (COVID-19). Krisis, Ancaman Glob Ekon Dampak, Dari. 2020;17(1):90-8.

5. Yamali FR, Putri RN. Dampak Pandemi Covid-19 Terhadap Ekonomi Indonesia. Ekon J Econ Bus. 2020;4(2):384-8.

6. Siagian TH. Mencari Kelompok Beresiko Tinggi Terinfeksi Virus Corona Dengan Discourse Network Analysis. J Kebijak Kesehat Indones. 2020;09(02):98.

7. Ika. Pakar UGM Paparkan Penyebab Lansia Rentan Terinfeksi COVID. www.ugm.ac.id. 2020.

8. Wahyu. Lansia dan Pemahaman Protokol Kesehatan di Masa COVID-19. kependudukan.lipi.go.id. 2020.

9. Armitage R, Nellums LB. COVID-19 and the consequences of isolating the elderly. Lancet Public Heal. 2020;5(5):e256.

10. Utami B. SBY Luncurkan Lagu Seputar Wabah Covid-19, Gandeng Musisi Beken. nasional.tempo.co. 2020.

11. KEPULAUAN MKB. Pemuda dan Mahasiswa di Liang, Banggai Kepulauan, Bagikan Masker Gratis. infopublik.id. 2020.

12. Kota D. Nenek Berusia 90 Tahun di TTS Dapat Masker Gratis. kupang.tribunnews.com. 2020.

13. ER H. Kapolres Jayawijaya Bagikan 50 Paket Sembako Kepada Warakauri. www.Tribratanews Papua.com. 2020.

14. Reportase R. Dapur Umum, Polres Mimika Distribusi 1.000 Nasi Kotak Kepada Warga Yang Tidak Mampu. www.repostasepapua.com. 2020.

15. Runggat F. PMI Matim Bagi Sembako dan Masker untuk Lansia, Difabel dan ODGJ. www.timexkupang.com. 2020.

16. ER H. Dapur Umum Polresta, 300 Bungkus Dibagikan Kepada Purnawiran Polri dan Warakauri. www.Tribratanews Papua.com. 2020.

17. Jambi redaksi dinamika. PKK Peduli Covid-19, Sasaran Lansia dan Janda Tua. www.dinamikajambi.com. 2020.

18. Hasan. Akhirnya Disabilitas dan Lansia Purwakarta Terima Sembako Kemensos. www.onlinemetro.id. 2020.

19. Merodio G, Ramis-Salas M, Valero D, Aubert A. How much is one life worth? The right to equity healthcare for improving older patients' health infected by COVID-19. Sustain. 2020;12(17).

20. Daoust JF. Elderly people and responses to COVID-19 in 27 Countries. PLoS One. 2020;15(7):1-13.

21. Adriani, Wirjatmadi. Peranan Gizi dalam Siklus Kehidupan. Jakarta: Kencana; 2012.

22. Rossa V, Dinda R. Kenapa Lansia Perlu Dapat Perhatian Khusus di Tengah Pandemi Covid-19? 
www.suara.com. 2020.

23. Ridarineni N. Lansia Masih Alami Stigma Negatif. www.republika.co.id. 2018.

24. Turana Y.. Risiko Kematian Lansia dengan COVID-19 Tinggi tapi Pelayanan Kesehatan Belum Berpihak pada Mereka: Apa yang Harus Dilakukan. www.theconversation.com. 2020.

25. Tan RG. Meningkatkan Pelayanan Kesehatan dan Kesejahteraan Lansia di Era New Normal. www.manajemenrumahsakit.net. 2020.

26. Huchet E, Georgantzi N. Agesim in The Age of COVID-19. Opinion for Each Other. www.eachother.org.uk. 2020.

27. Pramono LA, Fanumbi C. Permasalahan Lanjut Usia di Daerah Perdesaan Terpencil. Kesmas Natl Public Heal J. 2012;6(5):201.

28. Ika N. Perlindungan Sosial dan Peran Perempuan. Lansia di Era COVID-19. 2020.

29. Ceccato I, Palumbo R, Di Crosta A, La Malva P, Marchetti D, Maiella R, et al. Age-related differences in the perception of COVID-19 emergency during the Italian outbreak. Aging Ment Health. 2020;in press(0):1-9.

30. Amalia AD. Evaluasi Proses Pelaksanaan Program Elderly Day Care Services Tahun 2012 Di Panti Sosial Tresna Werdha Budhi Dharma Bekasi Timur. 2012;(November):1-211.

31. Sarima A, Abdullah N, Hamiyati H. Hubungan Dukungan Sosial Keluarga Dengan Produktivitas Lansia. JKKP (Jurnal Kesejaht Kel dan Pendidikan). 2017;4(1):33-8.

32. Ayalon L, Chasteen A, Diehl M, Levy BR, Neupert SD, Rothermund K, et al. Aging in Times of the COVID-19 Pandemic: Avoiding Ageism and Fostering Intergenerational Solidarity. J Gerontol B Psychol Sci Soc Sci. 2021;76(2):e49-52.

33. Santoso MDY. Dukungan Sosial Meningkatkan Kualitas Hidup Lansia: Review Article. J Kesehat Mesencephalon. 2019;5(1):33-41. 